\title{
Religion in the Culture \\ of the Altai-Sayan Peoples: \\ Historical and Philosophical Analysis
}

\author{
Olga M. Khomushku* \\ Tuva State University \\ 36 Lenina Str., Kyzyl, 667000, Russia
}

Received 28.01.2017, received in revised form 20.02.2016, accepted 25.03.2017

The article is devoted to the issues of the role and importance of religion in the culture of the AltaiSayan peoples. The author gives an analysis of the development of cultural and religious traditions in Tuva, the current state of religiosity in the country; investigates the specificity of multi-confessional culture and peculiarities of the different religious systems prevalent in the region. On the basis of extensive factual material the characteristic of interaction and mutual influence of the main Tuva religions - Buddhism, Shamanism, Tengrism, Christianity etc. Modern religious situation in the region is considered against the background of continuing growth of interest in religion, the revival of folk traditions, customs, celebrations and rituals.

Keywords: religion, culture, Buddhism, multi-religious culture, Orthodoxy, Old Believers, Shamanism, Tengrism, the peoples of Sayano-Altai.

DOI: 10.17516/1997-1370-0057.

Research area: culture studies.

The modern structure of religions and confessions in Russia is the result of a historically long and difficult process. For the peoples of the Altai-Sayan (also spelt as Sayan-Altai) mountains (as well as for any other people) religion has always been the reflection of the results of their practical activities, spiritual and practical learning about reality and the expression of their inner needs and aspirations. Being the regulator of the social activity of any personality, it has also been the way of consolidation and transfer of ethnocultural information to future generations. In this case the religious world regulates the behavior of a person through its system of values. The religious consciousness develops moral standards, political and ideological orientations; assumes an attitude towards the world, creating a certain picture of the world, its own way of explaining the social reality, thus performing a regulatory function, the content of which is determined by the specific nature of the developing society.

A historically established constant relationship between certain ethnic groups and religions is reflected in the spiritual image and national culture of the ethnic groups. This is the role of Orthodoxy in Russian history and culture

(C) Siberian Federal University. All rights reserved

* Corresponding author E-mail address: hom17@mail.ru 
as well as Islam, Buddhism, etc. Spreading to new territories, these religions influenced the local beliefs and following syncretization the autochthonous beliefs either interacted with the religions or were absorbed by them, but never disappeared completely.

In the culture of the Altai-Sayan peoples the customs, traditions and religions of different peoples and civilizations usually interact and influence each other. Thus, the cultural and historical traditions, reflected in the developing ideological archetypes, had an important feature that in turn influenced the formation of religious and syncretic complex. The Altai-Sayan model represents the religious and social complex which enables reproduction and interacts with the similar social institutions in the traditional structure of the Altai-Sayan society where different cultural and religious traditions have interacted with a common ethnic and cultural background of the "nomadic" civilization (Abaev, Khomushku, 2010).

Therefore, it is obvious that one should observe a growing interest concerning the preservation and revival of culture, including the culture of the Altai-Sayan peoples. In the article the author will focus primarily on contemporary processes taking place in Tuva, among the Tuvans, their traditional spiritual values and guidelines, including religion.

The Tuvan people had a fairly coherent system of cosmogonic myths which explained the origin of the universe and people, the main myth themes were the harmony of the universe, the existence of man in the universe, the universe integrity given that the universe is multilayered and multidimensional.

Such ethnic and religious integrity was not destroyed by the arrival of Buddhism, which assimilated the traditional ritualism, transforming it, maintaining its structural integrity and original cult meaning.
The spread of Buddhism on the territory of the Altai-Sayan mountains led to the emergence of syncretism on the basis of interaction with the traditional beliefs of the Altai-Sayan peoples and Tuvinians as well. With the spread of Tibetan Buddhism on the Altai-Sayan territory, it assimilated the autochthonous cults intensively, retaining some ethno-cultural specificity of the local and areal variations of the region.

As a result of the transformation of folk beliefs and cults the Tuvan form of Buddhism started to develop. As in any other national form of religion, there are two levels in the Tuvan Buddhism: refined philosophical and mystical Buddhism, studied and interpreted by the higher clergy, the lamas; and folk Buddhism, i.e. Buddhism of the populace.

Before the arrival of Russian settlers (in the $19^{\text {th }}$ century) the population of Tuva was monoethnic; according to the type of traditional way of farming the indigenous inhabitants were the taiga nomad-shepherds and reindeer-breeders (hunters and anglers). Traditional religions were Shamanism and Buddhism.

The arrival of Russian people gradually changed not only the ethnic and linguistic but also religious situation in Tuva. The Russian population has brought not only the Russian language, but also the Christian faith - Orthodoxy, which represented the official religion of the former Russian Empire, as well as the Old Believers, and Protestantism in the form of Evangelical Christians - Baptists.

The Trinity Orthodox Church in the city of Kyzyl was built in 1914 (the first Orthodox Church in Tuva was built in the city of Turan in 1910, it was demolished in 1961 and rebuilt in 1996). In the beginning of the century the necessity of construction of a Christian Church in such a remote location was discussed in the business correspondence between the clergy of the Krasnoyarsk territory and the Resettlement 
Department of the Uriankhai. So, in the letter to the Bishop of Yeniseysk and Krasnoyarsk, it was noted that "in order to attract interest of the aboriginal people, it is necessary to show them the beauty, solemnity and deep meaning of our Orthodox divine services in comparison with their religious rites".

The Old Believers in Tuva traditionally settled in places such as Kaa-Khem, Tandy, Todzhu, Tes-Khem according to the Belokrinitskii agreement.

In 1918, in the upper reaches of the Yenisei Old Believers founded a convent, in which there were about 25 nuns by 1928 .

The complexity of today's religious situation in Tuva is determined by its multi-religious reality which is characterized by two tendencies: the revival and the development of traditional religious beliefs and the growing influence of the new religions that did not exist in the area before.

For many years (until the 1980s) the freedom of spiritual choice had meant freedom only in relation to an atheistic orientation. Traditional beliefs of Tuvans, such as Buddhism, Shamanism, were considered as "remnants of the past", and in the informational reports about the activities of religious organizations few priests (lamas, shamans) were described as "clandestine lamas and shamans".

Strict repressive actions against religious institutions were taken since the beginning of the 1930s, such policy was given in January 1929 at the Plenary session of the Central Committee, after that the Presidium of the Small Hural (local parliament) adopted a special resolution, according to which the Church lost its property, and the clergy did not have the right to get any support from the national government and lost many civil rights.

A tide of repressions occurred throughout Tuva. Almost all the monasteries and dugans were closed down. So, in Dzun-Khemchiksky District there were two influential Khurees (temples), one of which was built in 1878, the other in 1907, in both monasteries in 1929 about 350 lamas (priests) conducted a service of worship, a year later (after the adoption of the above mentioned resolution) there were only 36 lamas left, in 1931 - 3, and in 1932 there were no lamas anymore (Khomushku, 2014).

The same fate befell the Orthodox Christians and the Old Believers: aggressive atheistic policy of the Soviet authorities and their desire to keep everything under control intervened with religious and family matters of the Orthodox Christians and the Old Believers conflicted with the authorities and the government.

Shamanism also was in the list of harmful remnants of the feudal past which were to be eradicated. However, its advantage consisted in the fact that shamanic cult places were far away from the sight of the official authorities - it was practiced on high mountains, in tribal areas, near water sources in forests, which allowed it to escape complete physical destruction.

In the years of the Soviet regime the Trinity Church in Kyzyl miraculously survived. The reasons, why the government of the USSR and Tuva took this step, were political: firstly, to prove that in socialism there is freedom for any religion, including the Orthodoxy in the region where people have traditionally practiced Shamanism and Buddhism.

The annexation of Tuva by the USSR in 1944 determined the character of the state of religion in the republic. By the beginning of 1940s on the territory of Tuva there was no Buddhist monastery left. The exception was the Chadanskii monastery. Despite the fact that their building was completely destroyed, a small group of the survived lamas continued conducting the worship services. Some witnesses said that several lamas were trying to save the Khuree by moving it to another location. 
In the area of Teve-Khaya, near the Chadanskii valley, they put up six yurts for shelter and built two houses of worship, then they began to receive people, to conduct the worship services and religious ceremonies. The initiator of this project was lama Mongush Chymba. At the time of establishment of worship houses (1946) there were only six lamas; by 1947 their number had increased to nine. From 1946 to 1953 the prior of this unique Khuree was lama Homoshku Amyrta (born in 1893), a native of Barun-Hemchikskii district, the son of a famous lama who studied in Urga since the age of eight, and in 1913-1926 served in one of Ulan-bator (Urga) monasteries. After his death, Chamyldai Tulush (born in 1912) was promoted to this position, a native of Chaa-Khol district, he had the scholarly degree of khelin (Tibetan gelong). He was in charge of the Khuree from 1953 to 1958; lama Tulush TereKombu (born 1897) replaced him, a native of Chaa-Khol district, he had an academic degree of keshpi (Tibeta Geshe). In addition, close contacts were established with the Ivolginskii datsan, a group of Tuvan lamas under the leadership of Khomushku Kenden who was sent to this temple; his name is well known not only in Tuva, but also in Buryatia.

In 1960, a considerable amount of money (for those times the sum was 45 million rubles) was donated by the believers for the construction of a temple. Despite the growing popularity of religious activity among the population and repeated requests of lamas for the permission to register the Buddhist community, the permission for the temple construction was not given by the authorities. And in 1960 the last Buddhist centre in Tuva was closed. Extra-institutional practice began to displace the institutional one, priests started to conduct services and carry out rituals and ceremonies secretly.

The government policy towards religious organizations was quite harsh, not only in relation to Buddhists and shamanists, but also Christian, although there were no specific directives and instructions regarding the prohibition of their registration and infringement of the believers' rights. Moreover, any religious service was allowed to be conducted, but in fact, doing so was almost impossible. Members of religious communities were under control of the Communist Party covertly, indeed, they were deprived of freedom of religious liberty.

In these circumstances, many lamas and shamans had to conduct private religious services illegally; their activities were under close supervision of the relevant authorities.

According to the statistics, in 1981 in cult practices in Tuva 12 lamas and 24 shamans were engaged; in 1984-11 lamas and 38 shamans. In the reports of the Party authorities it was mentioned that the number of lamas was reducing every year due to the natural diminution, but instead of them shamans-pretenders appeared.

Perestroika in the sphere of ideology, especially in such a delicate area as traditional religious beliefs and new religious movement, started in 1988, when Russia celebrated the $1000^{\text {th }}$ anniversary of the Cristianization of Rus' and the dialogue between religious and secular authorities of the country began concerning "the place of religion in history and culture".

For Tuva it was the chance for the revival of traditional spiritual culture, and, of course, religion as its integral part. In January 1990 the existing Buddhist organization Aldyn Bogda was officially registered on the basis of the decision of the Religious Affairs Council in Tuva. In the summer of 1990 some religious rituals, which had been banned before, were officially conducted. So, the traditional New year Shagaa was again included into the Tuvan calendar. Its revival, however, as well as other traditional rites and customs, was quite difficult, because the old administrative system and Communist 
ideology strongly influenced this process. For the first time Shagaa was held in the building of the Tuvan Music Drama theatre in 1987, in 1989 the government of the Republic suggested to celebrate Shagaa according to the lunar-solar calendar annually.

The first Buddhist temple, marking the revival of Buddhism in Tuva, appeared in the late 1990s in Kyzyl-Dag, Bay-Tayginsky District. The initiators of its construction were local artists and stone-carvers Saaya Kogel and Sergey Kochaa. The temple inauguration took place on the $27^{\text {th }}$ of December in 1990, the rite of sanctification was performed by the former lama, the 94year-old Kuular Symbi-ool, who studied in the Verkhnechadanskii Khuree. In the summer of 1991, the temple held a festival dedicated to the gyre Buddha Maitrey. In May 1991, the first issue of Erege appeared - the journal of the Buddhist society Aldyn Bogda with the total circulation of 4 thousand copies. By the invitation of the same society two Mongolian lamas Dazhravjaa Ravja and Dash Tsultam visited Tuva. At the same time in Kyzyl on the right bank of the Yenisei river a number of yurts-chapels were mounted where lamas, invited from different districts of Tuva, conducted worship services and simple rituals. These yurts-chapels were open only during the warm seasons because of the complexity of their heating and winter maintenance. Later the first temple in Kyzyl was built on this place.

The visits of His Holiness the Dalai Lama XIV in September 1992 and Bogdo-Gaghan Dzhebsun Damba Rinpoche in September 1999 were the most important events in the life of Tuvan Buddhists.

The ceremonial opening of the Buddhist temple, the residence of the Kamby-Lama of Tuva, took place on the $9^{\text {th }}$ of October in Kyzyl.

Contemporary religious life in Tuva is characterized (as well as throughout Russia) by the increase in the number of religious institutions - Buddhist temples (dugans), prayer houses, religious and public organizations of different religious orientations, a growing interest in religious literature, the emergence of theological literature, not only in Russian, but also in the Tuvan language.

The growth of national consciousness continues and supports traditional values of spiritual culture, as many people link the preservation and revival of the national culture with the traditional religion.

The current state of Buddhism in Tuva is determined by quantitative and qualitative indicators. Qualitative indicators include the level of the clergy education, the level of knowledge about Buddhism among the laity, and finally, the inclusion of the tenets of Buddhism into everyday life - the knowledge and use of the Buddhist moral rules in daily practice.

Quantitative characteristics are the number of Buddhist temples, the number of communities, and finally, the number of educated Buddhist lamas from the local population.

Describing these indicators we can distinguish three stages in the development of modern Buddhism:

- the first stage began in the 1990s, during the time of changes, when the actual process of revival of traditional religious spirituality started, this stage is characterized by high activity of the laity - representatives of the intelligentsia teachers, doctors, etc., as there were no qualified clergy in that period because of the massive purges which took place in the 1930s. Moreover, in this period the first groups of Tuvan boys were sent to study in Ulan-Ude, St.-Petersburg and later to India;

- the second stage (late $20^{\text {th }}$ century - early $21^{\text {st }}$ century) is characterized by the impact of Tibetan lamas-teachers such as Geshe Jampa Tinele, as well as those who remained to work in Tuva - Geshe Lobsang of Topten, Dagba Gyatso 
and Pende Galsen, Tuvan khuuraks (future lamas) were sent to train and study in India systematically;

- the third stage (approximately last fiveseven years) - the emergence of the first Tuvan Buddhist lamas who got a fairly good education in India and returned to Tuva. They became involved in the religious life of the Republic as well as in a large number of Buddhist events, for example, lectures by spiritual teachers, large prayer services, mass participation of the Tuvan pilgrims in the training held by His Holiness the Dalai Lama XIV in India, collective retreats in Buryatia, etc.

According to the information given by the administration of the centralized religious organization "Association of Tuvan Buddhists", in 2013 in the Republic there were 108 lamas, including those who were in India (22), Mongolia (2) and Buryatia (12) - in total 36 people were abroad and 70 lamas conducted the worship services in Tuva. According to the same source, now in Kyzyl there are 48 lamas, most of them work in (or more accurately, are assigned to) the Khuree Tsechenling - 33 people, 12 people - to Khuree Tashipanenling (most of them are from the Erzinskii district, so people call this KhureeErzinskii. If we analyze the level of training of modern Tuvan lamas and schools where they were trained, it should be noted that among the lamas who work in Kyzyl there are only two lamas Khertek Aganak (kensur) and Uvamchaa Sherchin (emchi) who had studied and lived in India for 10 years. A large percentage of lamas studied in the Ivolginskii datsan and 17 people have diplomas, 2 people have higher secular education, which they got after in Buryat Agricultural Academy the Ivolginskii datsan, 13 lamas were khuuraks (students) in India, but for various reasons, after 4-5 years of training they came back to Tuva.

Modern religious situation in Tuva is characterized by its poly-confessional variety - according to the information of the Ministry of Justice, as according to the $12^{\text {th }}$ of December 2013, Tuva had 53 religious groups, including 23 of the Buddhist orientation, 11 organizations of the Russian Orthodox Church (ROC), 1 - of the Old Believers, 11 - Protestant (Christian) orientation, 8 - shamanic organizations.

Spiritual revival also affected other traditional faiths - Russian Orthodox and Old Believers churches.

So, in September 2011 His Holiness Patriarch of Moscow and all Russia Kirill visited Tuva and conducted the consecration of the new Cathedral built in the city of Kyzyl. On the $5^{\text {th }}$ of October 2011 the Holy Synod of the Russian Orthodox Church decided to form the Tuvan and Kyzyl diocese within the administrative borders of the Republic of Tuva. Archimandrite Feofan (Kim) was elected as the Manager of the newly formed diocese, his Episcopal ordination took place on the $30^{\text {th }}$ of October 2011.

As for the Old Believers, currently it is possible to say that despite years of official prohibition, traditional Old Believers' culture was preserved because they settled in far and inaccessible places and had a conservative way of life. Families managed to save traditions there, as well as in the Russian Orthodox Church. Their religious cult consists mainly of ceremonial and everyday activities.

In the city of Kyzyl the Old Believers' community of Russian Orthodox Old Believers Church was registered, it also relates to Belokrinitskii agreement.

A characteristic feature of the contemporary religious situation in Tuva is that in addition to a significant increase in the number of parishioners and supporters of historically established traditional ethnic and religious communities, new religions appeared in the Republic such as Protestants, Pentecostals, Jehovah's Witnesses, the followers of NSD ("new religious movements") - 
Krishnaits, TM, Bahaists, etc. There is no doubt that the new religions have a definite influence on the spiritual and cultural, social and ethnopolitical processes in the Republic. Modern society should be able to negotiate with different faiths and to study these new phenomena. For example, there are Evangelical Christians Baptists, Pentecostals, Jehovah's Witnesses among the Protestant religious associations in the Republic.

So the modern multi-religious life in the Republic of Tuva defines the further development of the processes. The presence of a large number of religions in Tuva is quite a positive phenomenon, indicating the freedom of religious choice. The inter-religious relations in Tuva are characterized by their tolerance and desire for inter-faith dialogue, there are a lot of joint charity events and activities involving representatives of different religions. In June 2013, the Buddhist-Orthodox Council, which consists of representatives of the clergy, scientists and public figures, was established. Its role is to coordinate joint activities of traditional religious organizations, to develop their dialogue, coordination, inter-religious, interethnic relations and prevent conflicts on ethnic and religious grounds.

In addition, an important moment in the development of spirituality and spiritual culture in the Republic is the introduction of the new school subject "Basics of Religious Cultures and Secular Ethics" in schools of Tuva (as in schools of Russia). In 2012, on the basis of the Tuvan State Institute of Retraining and Advanced Training there was a week-long seminar with the participation of Geshe Lhakdor - Director of Library of Tibetan manuscripts (Dharamsala, India) and honourableBarry Cerzina. The audience were mostly elementary school teachers and teachers of history and social sciences, teachers of Russian, the native language and literature. Besides, during the visits of guests there were meetings at the University and different schools of the Republic. Moreover, the scientific-practical conference "Education, Science, Religion in the Modern World: New Approaches" took place at the Tuvan State University; scientists of the University and the Tuvan Institute of Humanity Studies and a number of school teachers attended the conference and took an active part in the conference.

In order to coordinate the process of Buddhism expansion, in November 2013 the Center of Buddhism and Tibetan Studies was opened in the Tuvan State University with the support of the Head of the Tuvan government Kara-ool Sholban. The Centre of Buddhism and Tibetan Studies is a structural unit of the University, which was established with the purpose to develop scientific and educational activities in the field of Buddhist and Tibetan studies, methodology and methods of teaching the fundamentals of Buddhist culture and secular ethics, the development of scientific and methodological approach to research Buddhist texts. Currently, meetings with Buddhist teachers such as Geshe Lkhagdorom, honourable Barry Cerzin, Priyadarshi, Robert Thurman and other Buddhist scholars are held regularly in the Center. In September, the textbook by Abaev N.V., Khomushku O.M., Bicheldei U.P. "Buddhism in Central Asia: History, Basic Teachings and Culture" was presented in the Center.

For the further development of spiritual culture it is necessary to coordinate the actions of the clergy and scientific researches. The Center of Buddhist and Tibetan Studies at the local University as well as the Center of Russian culture and the Center of Tuvan culture can become coordinating links for this purpose, which requires a number of round tables and seminars with the participation of a wide range of motivated individuals such as clergy, teachers, believers and young people. 


\title{
References
}

Khomushku, O.M. (2010) Dukhovno-kul'turnye traditsii v geopoliticheskom i tsivilizatsionnom prostranstve Tsentral'noi Azii i Sayano-Altaia [Spiritual and cultural traditions in geopolitical and civilizational space of Central Asia and Sayan-Altai mountains]. Kyzyl, 180 p.

Khomushku, O.M. (2014). Tengri i burhany [Tengri and Burhans], 7, 37-39.

\section{Религия в культуре народов Саяно-Алтая: исторический и философский анализ}

\author{
О.М. Хомушку \\ Тувинский государственный университет \\ Россия, 667000, Республика Тьва, \\ Кьзыл, ул. Ленина, 36
}

\begin{abstract}
В статье освещуаются вопросы о роли и значении религии в культуре народов Саяно-Алтая. Дается анализ развития культурных и религиозных традиций в Туве с обзором текущей ситуации с религиозностью в этом регионе. Автор исследует многоконфессиональную культуру и особенности различных религиозных систем, преобладающих в этом регионе. На основе обширного фактического материала характеризуется взаимодействие и взаимное влияние тувинских проявлений буддизма, шаманизма, тенгрианства, христианства и т.д. Современная религиозная ситуация в регионе рассматривается на фоне непрерывного роста интереса к религии, возрождения народных традиций, обычаев, ритуалов и праздников.
\end{abstract}

Ключевые слова: религия, культура, буддизм, мультирелигиозная культура, православие, старообрядчество, иаманизм, тенгрианство, народы Саяно-Алтая.

Научная специальность: 24.00.00 - культурология. 